\title{
Changes in Apartment and Site Type Houses During Covid-19 Pandemic
}

\author{
Gonca Özer Yaman ${ }^{1 \odot}$, Elif Merve Erturan ${ }^{2 \odot}$, Ayșe Yıldırım Ateş ${ }^{3 \odot}$ \\ ${ }^{1}$ Asst. Prof. Dr., Faculty of Architecture and Engineering, Bingöl University, Bingöl, Turkey. Email: gozer@bingol.edu.tr \\ ${ }^{2}$ Res. Asst., Faculty of Architecture and Design, Konya Technical University, Konya, Turkey. (Principal contact for editorial \\ correspondence), Email: emerturan@ktun.edu.tr \\ ${ }^{3}$ Res. Asst., Faculty of Architecture, Akdeniz University, Antalya, Turkey. Email: ayildirim@akdeniz.edu.tr
}

\begin{abstract} Purpose

The purpose of this study is to reveal the deficiencies and the space features that people who have to spend more time in their homes during the Covid-19 epidemic process.

Design/Methodology/Approach

This research was conducted during the coronavirus pandemic, when individuals had to stay in their homes, spend more time at their homes and get to know their homes better. In this context, a questionnaire was applied to 400 residents living in the apartment and site (multi-block apartment). The obtained data were evaluated in the SPSS (Statistical Package for the Social Sciences) and the results were expressed in figures and tables.

\section{Findings}

The changes made by the users living in these residences in all spaces of the house (living areas, wet areas, night units, semi-open, open, etc.) and their evaluations for these spaces are presented in detail.

\section{Research Limitations/Implications}

The main limitations of this study are that residential users are directly included in the study process through questionnaires.

Originality/Value

As a result of the COVID-19 epidemic in the world, architecture was affected by this situation, as in many disciplines, and people started to rearrange their lives by taking measures against the risk of epidemics. Measures have been taken all over the world to reduce the risk of transmission of the epidemic, and curfews have been implemented. In the discipline of architecture, the spatial fictions that have continued until this time have been questioned, and people have been drawn to their residences against the risk of infection by the virus. Streets, avenues and squares in the cities remained empty and public spaces (shopping mall, cultural centre, sports centre, etc.) became unusable. This process enabled individuals to analyse their homes better and people realized the features they needed regarding the spaces they lived in during this process. In this study, the effects of this newly encountered process on residential spaces are revealed.
\end{abstract}




\section{INTRODUCTION}

People have the instinct to survive and continue their generation like other creatures. Since existence, people have built housings to meet their basic needs such as shelter, protection and security. The housings have different meanings for people rather than being the structure where only the accommodation requirement is met. People have internalized the housing. They also saw it as part of themselves, their families, and their lives. Le Corbusier has defined housing as the crowning of life. Again, Le Courbusier "When it comes time to build the house, then it is neither a bricklayer nor a technician; that moment is the moment of poetry created by every human being at least once in their lives." With this expression, likened the house to a poem that can be created once in a person's life (Courbusier, 2015). He also emphasized that the house user should be a determining factor in the design of the housing. Houses are affected by many factors such as economic, social, cultural and social factors of the age. Houses are the most common buildings as building stock, and their construction and demand from the past to the present is higher than other buildings. It is important that this type of building, which is numerous in cities and shapes the structural environment, is designed to meet the needs of the users. Houses contain many basic actions that people perform. People perform their basic actions such as sitting, sleeping, resting, preparing food, eating and cleaning in their homes. However, in the epidemic processes rarely encountered in human history, people had to spend more time in their homes. During the epidemic, people carried out different actions in their homes. These were included in the actions in the houses in activities such as hobby, work, learning, doing sports, watching movies, growing plants. Especially in the COVID-19 pandemic process, which has emerged recently and its effect is expected to last for many years, people carry out all the activities they do throughout the day in their homes. In this process, people have to do their jobs, education and social activities in their homes. As a result, the houses were unable to respond to some of the actions, or in order to perform these actions, people have to change their homes, change the functions of the spaces in the home or redecorate. It has been determined that especially living spaces have transformed into educational spaces even during the lesson (Erturan et al., 2020).

Pandemics are one of the most serious threats faced by human beings. During the coronavirus pandemic, quarantine was declared in many countries and societies had to spend a long time at home. During the coronavirus pandemic, where socialization is risky and people need to stay in their homes, people spent more time in their homes and had the opportunity to get to know their homes. Before the pandemic, they spent most of their time at workplaces, parks, gardens, cafes, restaurants, cinemas, and theaters. However, people have not left their homes all over the world, as there is a risk of people infecting each other with the Covid19 virus by touching the air or surfaces. People in the house tried to find different activities, especially thanks to the advanced technology, the rate 
of spending time on social platforms has increased many times. Organizing concerts, events, and symposiums remotely at home, giving education over the internet gave the users who spend very little time at home the opportunity to make changes to their individual spaces or the whole house. Epidemics are the kind of diseases that mirror us who we really are (Chotiner, 2020). It has been observed that in the fight against the epidemic, national combat programs are implemented and solutions are sought within the borders of the state (Özkoçak et al., 2020).

In line with the new crisis caused by the covid-19 pandemic that has emerged all over the world, it has become necessary to conduct new research and studies in the field of architecture, as in many disciplines. In this direction, when we look at the studies in the field of architecture, we see different disciplines and research topics. In his study, (Barbarossa, 2020) addressed the issue of new urban design studies in order to ensure continuity in transportation in line with the pandemic needs. carried out a study emphasizing the necessity of producing urgent solutions in the field of architecture, taking into account the pandemic process. Hercules and his friends emphasized that it is important for health to produce architectural solutions for the pandemic process (Hercules et al., 2020). In the study of (Ensarioğlu \& Ensarioğlu, 2020), the definition, scope and application principles of the concept of "universal design" were examined. It has been determined how these can change during and after the epidemic process, and what new initiatives can be developed. Studies show that this situation is important in terms of architecture and that it is necessary to produce solutions.

With this study, it was aimed to investigate how the preferences of individuals living in apartment-type houses were affected and changed in line with the situations that occurred during the covid-19 pandemic process. In order to create the conceptual framework of the study, first of all, apartment type houses and the development process of these houses are mentioned. Then, the types of spaces in the houses were mentioned. In the continuation of the study, epidemic diseases, the history of the pandemic process, the emergence of covid-19 and its effects are mentioned. In the field research part of the study, a questionnaire was applied to 400 users living in flats and multi-block sites in order to reveal the space features that people need in the places they live during the covid-19 pandemic process. With the survey study, it was requested to investigate the features of the spaces that the users living in apartmenttype houses or multi-block sites need in the spaces they live in due to the pandemic process and the changes they make in the spaces. And in this direction, it is aimed to reveal how the new situations in housing design will guide the space design. Within the scope of the survey, firstly, questions were asked to the users, questioning personal information and it was aimed to determine the effects of factors such as age, gender and education on housing preferences. Afterwards, they were asked about the characteristics of the places they lived in. In the continuation of the survey, it was questioned what kind of changes were made in the places 
they lived in during the pandemic process, the points they saw missing in the places and whether there were any changes in their venue preferences. The answers to the questionnaire questions applied in the continuation of the study were analysed in the SPSS program and the results were presented. With these data, it was questioned how the personal information of the users and the characteristics of the place they live affect the housing preferences of the individuals and the function changes they make in the places they live. In addition, it is aimed to investigate what kind of need arises by comparing the functional features they need in the house. In the conclusion part of the study, a methodology that can guide the designers is presented by revealing how the perspective of individuals who experience such a process has changed.

\section{THE CONCEPT OF HOUSING}

Houses have changed and developed continuously in parallel with the development of people from the early ages until today. Houses were first built to protect humans from wild animals and bad weather. In the early ages, houses were built for basic human needs. However, in the later times, the houses changed according to the age they were in and the needs of the housing user. In the past, people have discovered the needs of the housing by experiencing it and made different spatial analysis in the housings according to it. The fact that people are different from each other and have different demands requires different space analysis in the houses. In addition, people experience many changes in their lifetimes. Socio-economic, cultural, technological and family structure (growth, contraction, etc.) change the way of living in houses. Therefore, houses need to be designed flexibly for these changes. People feel happy, satisfied, and successful in their lives if they own the housings that suit their needs and lifestyles.

\section{Historical Development of Apartment Housing}

The construction of housing is the most justified occupation of every society, every civilization. In the past, houses had built horizontally and individually. Different housing typologies have developed with the effect of social, cultural and technological developments. Kostof stated that first multi-storey housing buildings was built before BC 500 in Mesopotamia (Kostof, 1995). With the effect of the Industrial Revolution that emerged at the end of the 18th century, today's apartment housing typologies have developed. The Industrial Revolution, which started in England, spread quickly to Europe. Large enterprises were established and mass production started with the start of mechanization and the use of steam power. Thus, workforce was needed in enterprises and it was attractive for people to work in these enterprises during these periods of unemployment. Immigration to the cities were increased rapidly. In the cities, there was not enough housing stock for the incoming migration density. There was a need for houses that would meet everyone's needs and that could be produced quickly. 
As a result of the changes in social life with the Industrial Revolution, people's lifestyles have changed. As a result of industrialization, economic, social and cultural changes have changed the architecture, the structure and usage of the houses. There have been changes in the way of use of the houses and the interior layout with the changing world order. (Balamir, 1994) stated that not only the industrialization revolution was effective in the development of the apartment house, but also it had economic, political, architectural and socio-cultural effects. In addition, Balamir stated that apartment buildings are a new model in terms of form and meanings, although they have many features of the houses produced in previous periods.

Bozboğan stated that the construction of apartment housing types in Europe began in the 17th century but began to appear in the Ottoman Empire at the end of the 19th century (Bozboğan, 2015). In addition, apartments were first seen in Galata and Beyoğlu districts in Istanbul, where non-Muslims are mostly located. Bozboğan stated that apartment buildings, which were first seen in big cities such as Ankara and Istanbul, started to be built in other Anatolian cities in the middle of the 20th century (Bozboğan, 2015). Görgülü stated that the first of apartment house of Turkey's was Decugis Apartment located in Istanbul's Beyoğlu, Turkey (Görgülü, 2016). Decugis Apartment was built in 1895. The apartment is used as Galata Hotel today.

In 1918, Tayyare Apartment is both multiple housing and is designed by Turkish architect for the first time. In many sources Tayyare Apartments is accepted as Turkey's first apartment house. The apartments designed

Figure 1.Decugis Apartment (Görgülü, 2015).

Figure 2.Tayyare Apartment (URL-9) by Architect Kemalettin Bey for people whose houses were burned down in the fire were called Harikzedegan (people suffering from fire) Apartments. Later, it was given to the Turkish Aeronautical Association and thus it was named as Tayyare Apartments by the public.
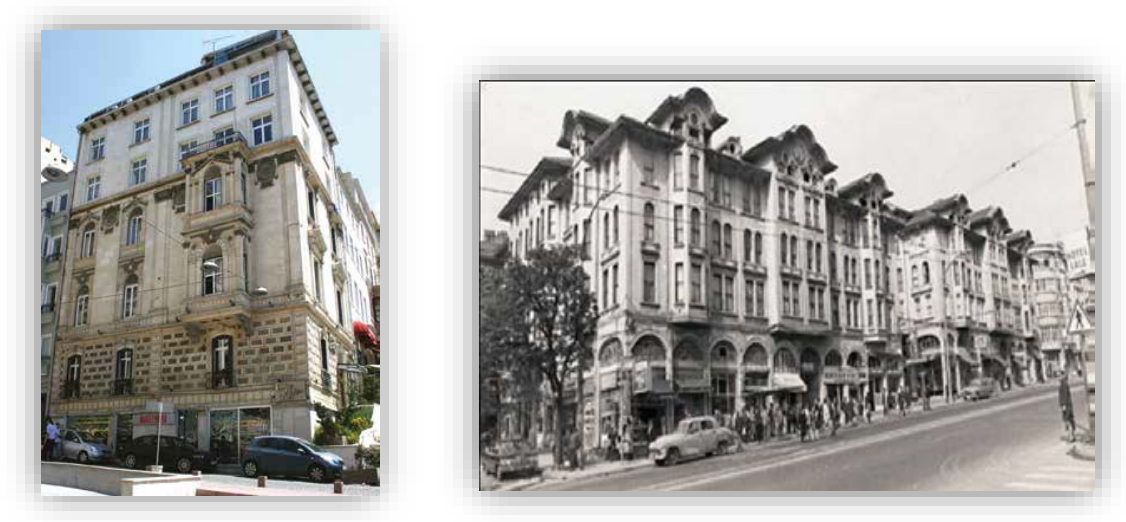

Migration from rural areas to cities, which started with the Industrial Revolution and continued until today, has increased. Thus, in cities with the increase in demand for housing and the increase in land prices, massproduced houses were produced. In general, apartment type houses have produced as mass production due to the land prices. As a result, the influence of houses users have decreased in housing design. Thus, people with different family, characteristics and cultural structure have to live in 
houses arranged one on top of the other with the same plan scheme. Uniform housing concept, which is a product of industrialized construction systems, cannot meet the different spatial needs of all people in the house. Realizing the problem in housing demand and production, Le Corbusier described the housing problem as the problem of the age. Moreover, Le Corbusier stated that the balance of societies depends on the solution of the housing problem. He also said that the construction of mass production houses is inevitable to meet the demands. He said that this new mode of production should be viewed from an impartial and critical perspective. Thus, he stated that he would eventually reach the healthy mass produced housing.

\section{Places in the House}

Shelter is one of the needs of people (Dinçer, 2005). The sheltering process, which started with tree burrows and caves, continues to the present day (Gündoğdu, 2019). Today, Houses are places where people's accommodation needs are met. Houses are used not only as shelters, but also as places where users meet their daily needs, spend their lives, and expand their families. In fact, residences are places where users spend a significant part of their time with their families (Parvaresh, 2013). Many actions have emerged over time in the houses. Food should be prepared in the kitchen, eaten in the dining room, laid in the bedroom, and daily actions should be carried out in the living space (Hacıbaloğlu, 1989). These actions are analysed and reveal the necessity of shaping the places in the house. The spaces that emerge from the need of the user in the dwelling are again shaped according to the needs. These needs are taken into account while determining the location in the building. Considering user needs and actions, we can define 3 different functions in housing space. The first one is living spaces, the second one is the sleeping places and the third one is the service places. In this section, brief information about the places in the residence will be given.

\section{Living Spaces (Daytime Living Spaces)}

The living space is often the largest multi-purpose space of houses, where users perform their activities in their active lives. Arcan and Evci defined the living space as the places where family residents sit together, communicate with the outside world indirectly through communication tools such as radio and TV, and are organized for the social needs of the houses (Arcan \& Evci, 1999). Places that spend time with family members or guests coming to the house during the day such as living room, guest room, living room and veranda can be evaluated in this group. In many areas in Turkey, there is a place where families and given the importance of having a larger size than the other rooms. This area is called a lounge or guest room. The guest rooms, which consist of sections such as sitting, hosting guests and eating, are flashy, large, bright and spacious (Alga, 2005). With changing user requirements, guest room culture has been gradually decreasing in recent years. It is seen that living room spaces 
Figure 3. Distance needed with sitting action

Figure 4. The living room distances in living spaces have transformed into a space that combines both the living room and the guest room functions.

There are some principles to be followed when planning living spaces. Usually it is planned living spaces of the house to the landscape orientation. Living spaces should be suitable for flexible arrangements according to time within the possibilities. The living space should be directly related to the entrance of the house. In this way, it will be ensured that the guests coming to the dwelling reach the living space without moving to the private areas. It is very important to determine the action areas in the living space. Areas of use emerge from action analysis. The figures below give the sitting action and the distances needed with this action.
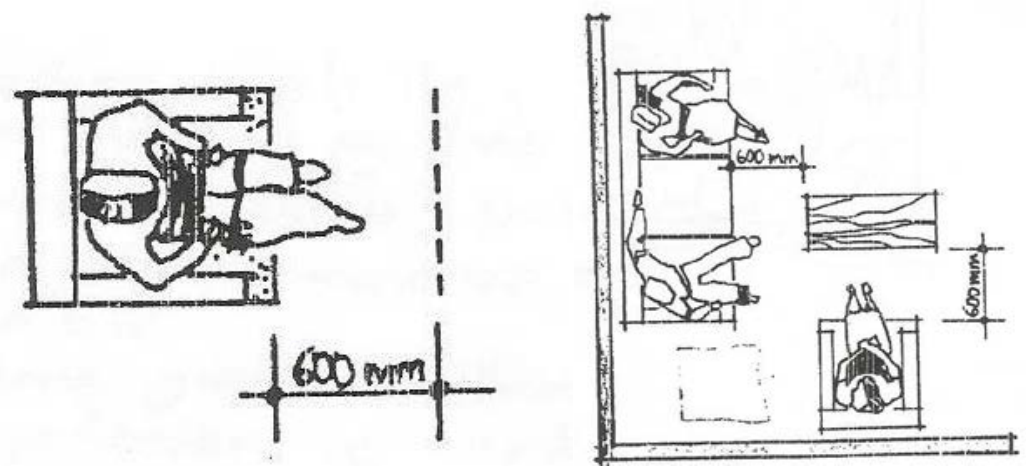

Users need a space of at least $60 \mathrm{~cm}$ in front of the seating element while performing the sitting action. Ministry of Education determined that the distance between the furniture and the required distance in front of the sitting element should be at least $60 \mathrm{~cm}$.

\section{Bed Places (Night Living Spaces)}

They are places where people sleep and rest. They are mostly used at night. Places such as parent bedroom, children's bedroom, guest bedroom can be evaluated in this group. Throughout history, the sign of status and wealth has been intimate spaces. The places where sleeping and resting activities are performed vary according to political and sociocultural events, periods, art movements, customs and traditions, lifestyle, materials and production technology. Sleeping is an action that allows the human body to rest mentally and physically. Physical environments needed for the act of sleeping should be created.

Therefore, sleeping areas in buildings are considered separately from other places today (Demirarslan, 2020). Figure 3 shows an example of a bedroom solution. It can be evaluated between the guest bedrooms or sleeping places. They are places created for the guests coming home to relax. 

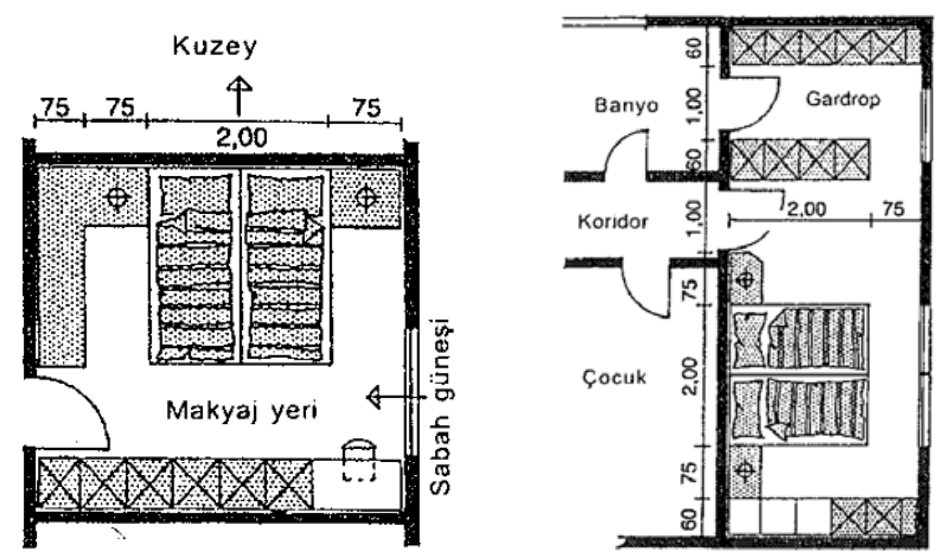

Another place in the sleeping areas is the children's room. The children's room is a place that allows the child to work, sleep and play with his siblings or alone (Bayazıt \& Yüksel, 1996). The spatial needs of the child change as the child gets older. The children's room should be a place planned considering the needs and activities of the child (Alga, 2005).

\section{Service Locations}

They are places used for activities that will help people's needs such as kitchen, toilet, bathroom, and warehouse. Research has shown that the living and service spaces of the residence are the most frequently used spaces and it has been revealed that the kitchen has an important place

591 in these spaces (Ylldırım, 1999). Actions such as storing, washing, cooking, preparing, serving and disposing of garbage are carried out in the kitchen space. In addition to these, some side actions such as watching $\mathrm{TV}$, ironing, sitting can take place in the kitchen. In addition to these, some side actions such as watching TV, ironing, sitting can take place in the kitchen. These actions depend on the socio-economic status, habits and cultural characteristics of the family, as well as the characteristics and size of the house (Gönen, 1990).

Bathrooms are another part of the service areas. Bathrooms are places that serve for the purpose of care and health and are also used to perform the washing action (Oruç, 2009). In some houses, small toilet spaces are also common along with the bathroom space. In some houses, there are also applications where dressing and shower rooms are considered in the parents' bedrooms. The bathroom solution is given in Figure 7 below.
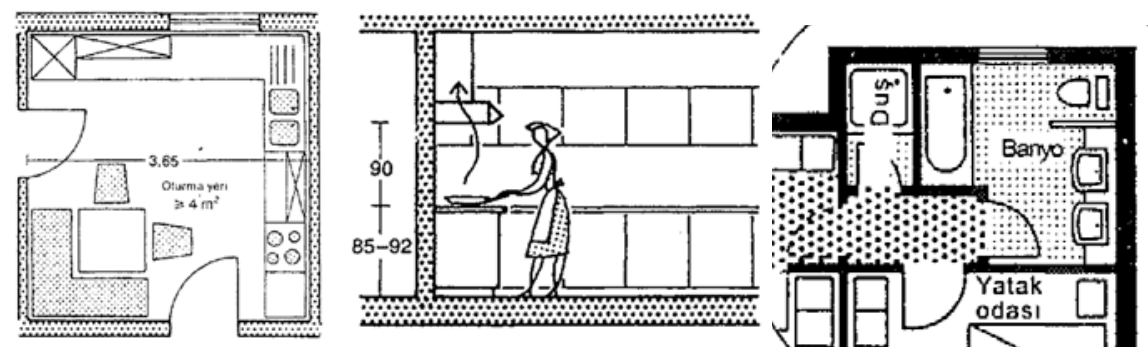

Figure 6. Kitchen space (Neufert, 1983).

Figure 7. Bathroom space (Neufert, 1983).

Figure 5. Bedroom example (Neufert, 1983). 


\section{PANDEMIC PROCESS AND ITS EFFECTS ON PLACES}

Diseases caused by pathogenic microorganisms such as bacteria, viruses, parasites or fungi that can pass directly or indirectly from one individual to another are called infectious diseases.

Epidemics have been cited throughout history as the main cause of mass deaths. In human history, it can be said that deaths from infectious diseases are more likely than deaths from wars (Esen, 2017) it is highly likely that a quarantine will be declared during the treatment of epidemics affecting the social, cultural and economic structures of societies. It is one of the most effective measures that can be taken to prevent the disease from taking effect without contacting people who may be infected.

\section{What is the Pandemic?}

In the historical period, the settled life of human beings began to make agriculture, agricultural products were sold in the markets began to trade more people came together with each other has increased epidemics. People who come in contact from various geographies have also become carriers of diseases.

Pandemic refers to a concept in the sense of "affecting all people" formed by the combination of the words "pan" meaning "all" and "demos" meaning "people" in ancient Greek (Aslan, 2020). The Word Healthy Organization (WHO) decides whether an outbreak is a pandemic.

According to the World Health Organization, the pandemic is considered to have started when three conditions are met; emergence of a disease that the population has not previously been exposed to disease-causing transmission to people and leading to danger the fact that the disease can spread easily and continuously among people (Yıldiz, 2017). The most effective way to prevent epidemics is to protect provinces, counties and endangered areas. Due to the quarantine, most of the individuals are protected in a way that they do not leave their homes. The Italian word "quaranta (forty)" for the duration of keeping the passengers under control against the spread of the plague, the quarantine (quarantena in Italian) was first implemented in Raguza in 1465 and in Venice in 1485. In the Ottoman Empire, the quarantine was named" usul-i tahaffuz "and the place was named" tehaffuzhane" (URL-3) the epidemic is an epidemic that spreads across a wide geography, but the pandemic refers to an epidemic that spreads globally.

The Spanish Flu (1918-1920), which is considered to be the largest outbreak and most affecting people's lives in history, has infected 1/5 of the entire population (URL-2). Spanish flu is known to have resulted in the deaths of 100 million people worldwide (Kırık et al., 2020).

19. at the beginning of the century, cholera, one of the major epidemics, spread all over the world and deeply affected the Ottoman Empire. Trade relations, Wars, migrations and pilgrimage to the Ottoman lands caused great economic losses (Ak, 2011). 
On March 11, 2020, the announcement of the Covid-19 outbreak as a pandemic occurred, and on March 13, 2020, the epicenter of the outbreak was changed to Europe (URL-1). Covid-19 poses concern to scientists as it contains uncertainties yet.

\section{Places formed due to pandemic (epidemic) in history}

Technological development, the easing of transportation, industrial foods, radiation and air pollution can also be cited as the causes that trigger outbreaks. In particular, people's social lives are heavily affected in pandemics, which can be passed from person to person and increase in cases where the social distance is not maintained. Outbreaks that can cause more casualties if health precautions are not taken also change users ' expectations of the venue.

In epidemic processes, people face many consequences psychologically as well. One of the most common behaviors is avoidance behavior. A survey of people quarantined due to SARS found that $54 \%$ of people avoid people who cough or sneeze, while $26 \%$ do not want to be in crowded areas (Reynolds. et al., 2008).

Depression, acute stress disorder, post-traumatic stress disorder, generalized anxiety disorder, panic disorder, somatic symptom disorders, other mood disorders, even psychosis can be seen as the danger increases, the disease spreads around them and the negativity increases in its course.

The outbreaks ended with a negative impact on the lives of many people, and states have erected many monuments on the occasion, thank God. It is possible to see praying, thankful and pleading motifs on the monuments found in the countries. (URL-4) It is common in European culture to think that outbreaks can be circumvented by erecting a monument (URL-5).

In Europe, church construction was also done with the wish to ask God for forgiveness and to remove the plague from them. The mosque was built by the Ottoman Empire, hoping for forgiveness from Allah. Hidayet mosque (URL-6) is one of these examples. The mosque is located on the site of the previous misbehaviour and therefore the epidemic spread in this area, thinking that the name of the destroyed Hidayet (the path of Allah, the right path) was determined as (URL-8).
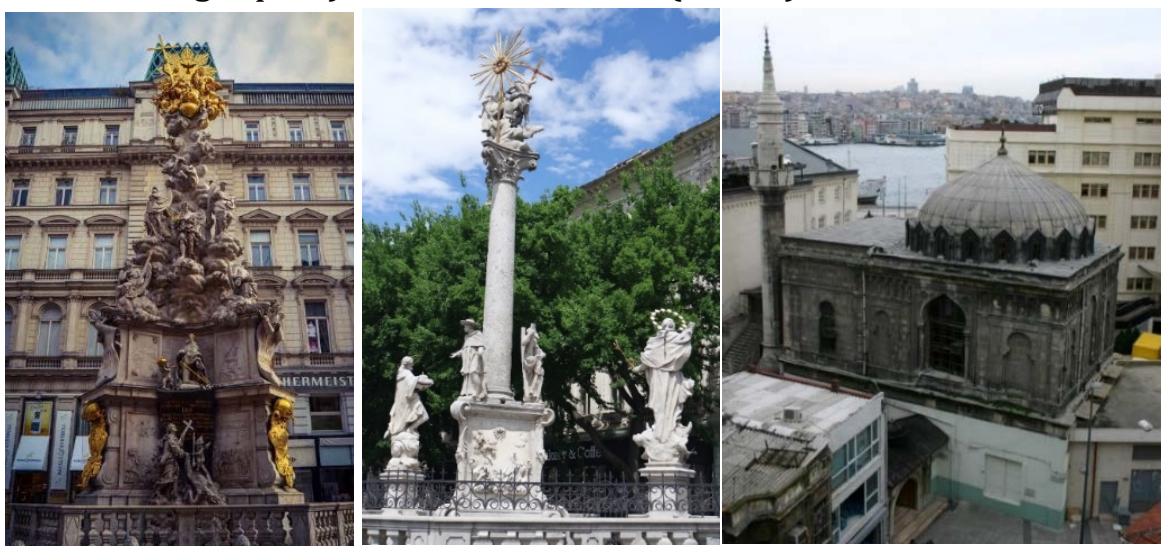

Figure 8. Plague Column Vienna and Holy Trinity Column Bratislava (URL-4 ve URL-5).

Figure 9. Hidayet Mosque. 
Tahaffuzhane is the name given to places built against epidemics during the Ottoman Empire and allocated for patients to spend a certain period of time. Tahaffuz means to avoid, to protect in Arabic (Pakalın, 1983). people were disinfected in Tahaffuzhane while their belongings were disinfected in Tebhirhane in the same complex. Tebhir means steam (URL-7). Each municipal office opened temporary cholera hospitals in its districts and undertook the treatment of patients in a short period of time. Three tebhirhane/disinfection stations were built and put into operation in Galata, Üsküdar and Tophane. The places where cholera is seen and the items brought here have been disinfected (Yıldırım, 2015). There are 3 registered quarantine Islands in the world: Elisa Island in the USA, Dubrovnik island in Croatia and quarantine island in our country. Urla Tahaffuzhanesi, located in our country, was designed for trade ships, cruise ships and pilgrims coming all over the country for the pilgrimage route, and continued to operate actively until 1950 (URL-7).

$\begin{array}{ll}\text { Figure } \quad \mathbf{1 0 .} & \text { Urla } \\ \text { Tahaffuzhane (URL-7). } & \end{array}$

Figure 11. Gedikpaşa Tebhirhane, (Yıldız, 2015)
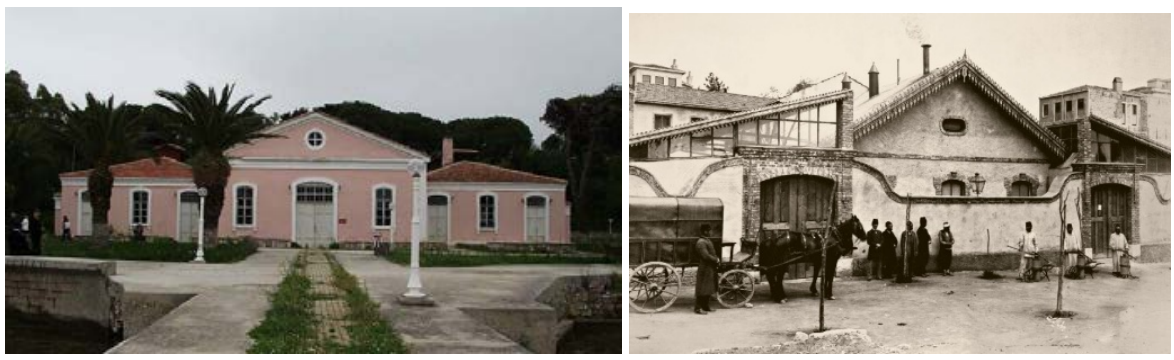

As a result of the Covid-19 pandemic, the places most needed have been Hospitals. Considering that construction technologies like today did not exist in the past, it can be predicted that the mortality rates of patients who did not receive treatment due to the fact that hospital construction processes did not take place quickly. However, today, prefabricated hospitals around the world have been completed and started to provide services within weeks, thus increasing the number of inpatient patients. Another place needed as a result of the pandemic is undoubtedly the parks and recreation areas where social distance can be provided. People needed breathing and non-crowded environments, especially due to the destruction of green spaces as a result of distorted urbanization. Due to the lack of such spaces, people had to spend more time in their housing, and because they spent most of their time in the housing, they needed some changes.

\section{FIELD RESEARCH}

Within the scope of the study, a survey was conducted to investigate the effect of the Covid-19 pandemic. The survey was applied to 400 residential users living in apartments or estates over the internet. With the questionnaire, the personal information of the users was first questioned and then questions about the type of residence lived in were included. In addition, the questionnaire included questions about the 
residence and its surroundings that were experienced during the covid19 pandemic process, and the space features needed by the users. The answers given to the questionnaire were evaluated in the SPSS program. In this section, the statistical results of the survey application will be included.

\section{Survey Results}

In the questionnaire, the questions containing the personal information of the residential users were primarily included. The results of the answers given to the questions about age, gender and education status of the residential users who were surveyed are given in the table below.

Table 1. Personal information of the respondents

\begin{tabular}{|c|c|c|c|c|c|}
\hline \multicolumn{6}{|c|}{ Age } \\
\hline & & Frequency & Percent & $\begin{array}{c}\text { Valid } \\
\text { Percent }\end{array}$ & $\begin{array}{c}\text { Cumulative } \\
\text { Percent }\end{array}$ \\
\hline \multirow[t]{5}{*}{ Valid } & $14-19$ & 40 & 10,0 & 10,0 & 10,0 \\
\hline & $20-30$ & 163 & 40,8 & 40,8 & 50,8 \\
\hline & $31-45$ & 129 & 32,3 & 32,3 & 83,1 \\
\hline & $46-60$ & 64 & 16,0 & 16,0 & 99,1 \\
\hline & 61 and over & 4 & 1,0 & 1,0 & 100,0 \\
\hline \multicolumn{2}{|l|}{ Total } & 400 & 100,0 & 100,0 & \\
\hline \multicolumn{6}{|c|}{ Gender } \\
\hline & & Frequency & Percent & $\begin{array}{c}\text { Valid } \\
\text { Percent }\end{array}$ & $\begin{array}{l}\text { Cumulative } \\
\text { Percent }\end{array}$ \\
\hline \multirow[t]{3}{*}{ Valid } & Female & 278 & 69,5 & 69,5 & 69,5 \\
\hline & Male & 122 & 30,5 & 30,5 & 100,0 \\
\hline & Total & 400 & 100,0 & 100,0 & \\
\hline \multicolumn{6}{|c|}{ Education Status } \\
\hline & & Frequency & Percent & $\begin{array}{c}\text { Valid } \\
\text { Percent }\end{array}$ & $\begin{array}{c}\text { Cumulative } \\
\text { Percent }\end{array}$ \\
\hline \multirow[t]{6}{*}{ Valid } & $\begin{array}{l}\text { Primary } \\
\text { school }\end{array}$ & 11 & 2,8 & 2,8 & 2,8 \\
\hline & $\begin{array}{l}\text { Secondary } \\
\text { School }\end{array}$ & 36 & 9,0 & 9,0 & 11,8 \\
\hline & High school & 59 & 14,8 & 14,8 & 26,5 \\
\hline & University & 236 & 59,0 & 59,0 & 85,5 \\
\hline & $\begin{array}{l}\text { Master or } \\
\text { PhD }\end{array}$ & 58 & 14,5 & 14,5 & 100,0 \\
\hline & Total & 400 & 100,0 & 100,0 & \\
\hline \multicolumn{6}{|c|}{ What is the number of people you live together? } \\
\hline & & Frequency & Percent & $\begin{array}{r}\text { Valid } \\
\text { Percent }\end{array}$ & $\begin{array}{l}\text { Cumulative } \\
\text { Percent }\end{array}$ \\
\hline \multirow[t]{6}{*}{ Valid } & Single & 27 & 6,8 & 6,8 & 6,8 \\
\hline & 2 & 78 & 19,5 & 19,5 & 26,3 \\
\hline & 3 & 84 & 21,0 & 21,0 & 47,3 \\
\hline & 4 & 112 & 28,0 & 28,0 & 75,3 \\
\hline & 5 and over & 99 & 24,8 & 24,8 & 100,0 \\
\hline & Total & 400 & 100,0 & 100,0 & \\
\hline
\end{tabular}

When we look at the answers given about the age of the respondents in the table, $10 \%$ are between the ages of $14-19,40.8 \% 20-30,32.3 \% 31-45$, $16 \% 46-60$ and $1 \%$ is over 61 years old. The majority of respondents are in the 20 -30 age range. $69.5 \%$ of the respondents are women and $30.5 \%$ are men. $2.8 \%$ of the respondents have primary school, $9 \%$ secondary 
school, $14.8 \%$ high school, 59\% undergraduate, $14.5 \%$ graduate education level. Participants mostly have undergraduate education level. The statistics of the answers given by the respondents to the questions about the houses they live in are given in the table below.

Table 2. The answers given to the questions about the house where the participants live

\begin{tabular}{|c|c|c|c|c|c|}
\hline \multicolumn{6}{|c|}{ What is the type of the house you live in? } \\
\hline & & $\begin{array}{l}\text { Frequen } \\
\text { cy }\end{array}$ & Percent & $\begin{array}{c}\text { Valid } \\
\text { Percent }\end{array}$ & $\begin{array}{l}\text { Cumulat } \\
\text { ive }\end{array}$ \\
\hline \multirow{4}{*}{ Valid } & Apartment & 262 & 65,5 & 655 & 65,5 \\
\hline & Site (multi-block & 138 & 345 & 345 & 1000 \\
\hline & $\begin{array}{l}\text { apartment) or Gated } \\
\text { communities }\end{array}$ & 100 & $34, \mathrm{~J}$ & 34,3 & 100,0 \\
\hline & Total & 400 & 100,0 & 100,0 & \\
\hline \multicolumn{6}{|c|}{ How many rooms do you live in? } \\
\hline & & $\begin{array}{l}\text { Frequen } \\
\text { cy }\end{array}$ & Percent & $\begin{array}{c}\text { Valid } \\
\text { Percent }\end{array}$ & $\begin{array}{l}\text { Cumulat } \\
\text { ive } \\
\text { Percent }\end{array}$ \\
\hline \multirow[t]{6}{*}{ Valid } & $1+1$ & 7 & 1,8 & 1,8 & 1,8 \\
\hline & $2+1$ & 60 & 15,0 & 15,0 & 16,8 \\
\hline & $3+1$ & 263 & 65,8 & 65,8 & 82,5 \\
\hline & $4+1$ & 60 & 15,0 & 15,0 & 97,5 \\
\hline & $5+1$ & 10 & 2,5 & 2,5 & 100,0 \\
\hline & Total & 400 & 100,0 & 100,0 & \\
\hline \multicolumn{6}{|c|}{ Is there an elevator in your house? } \\
\hline & & $\begin{array}{l}\text { Frequen } \\
\text { cy }\end{array}$ & Percent & $\begin{array}{c}\text { Valid } \\
\text { Percent }\end{array}$ & $\begin{array}{l}\text { Cumulat } \\
\text { ive } \\
\text { Percent }\end{array}$ \\
\hline \multirow[t]{3}{*}{ Valid } & Yes & 290 & 72,5 & 72,5 & 72,5 \\
\hline & No & 110 & 27,5 & 27,5 & 100,0 \\
\hline & Total & 400 & 100,0 & 100,0 & \\
\hline
\end{tabular}

When the respondents were asked about the type of house they live in, according to the answers; $65.5 \%$ of them live in a single block apartment, and $34.5 \%$ live in the site (multi-block or secure site). When asked about the number of rooms, $1.8 \%$ of the respondents live in $1+1$ residences, $15 \% 2+1,65.8 \% 3+1,15 \% 4+1,2.5 \%$ lives in residences with $5+1$ rooms. When asked whether there is an elevator in the residence, $72.5 \%$ of the respondents have an elevator, $27.5 \%$ do not have an elevator.

When the users were asked about their housing preferences during the pandemic process and whether they made any changes in their houses, the results in the following table were obtained.

When the respondents are asked whether their housing preferences have changed; $36.5 \%$ of them stated that their housing preference changed during the pandemic process, while $63.5 \%$ of them stated that the housing preference did not change. When the respondents are asked whether the function of any space has changed during the pandemic process; $9.5 \%$ of them made changes in their home during the pandemic process, $90.5 \%$ did not change their home. $9.2 \%$ of the respondents stated that they bought sports equipment at home during the pandemic 
process, and $90.8 \%$ did not. 58 people participating in the survey have adopted pets during the pandemic process.

In the table below, the statistics of the answers given to the questions about whether there is a change in the general activities of residential users during the pandemic process are given.

Table 3. Responses to questions about users' housing preferences and whether they have made any changes in their homes during the pandemic process

\begin{tabular}{|c|c|c|c|c|c|}
\hline \multicolumn{6}{|c|}{ Have your housing preferences changed during the pandemic process? } \\
\hline & & Frequency & Percent & $\begin{array}{c}\text { Valid } \\
\text { Percent }\end{array}$ & $\begin{array}{l}\text { Cumulative } \\
\text { Percent }\end{array}$ \\
\hline \multirow[t]{3}{*}{ Valid } & Yes & 146 & 36,5 & 36,5 & 36,5 \\
\hline & No & 254 & 63,5 & 63,5 & 100,0 \\
\hline & Total & 400 & 100,0 & 100,0 & \\
\hline \multicolumn{6}{|c|}{ Have you changed the function of any place in the pandemic process? } \\
\hline & & Frequency & Percent & $\begin{array}{c}\text { Valid } \\
\text { Percent }\end{array}$ & $\begin{array}{l}\text { Cumulative } \\
\text { Percent }\end{array}$ \\
\hline \multirow[t]{3}{*}{ Valid } & Yes & 38 & 9,5 & 9,5 & 9,5 \\
\hline & No & 362 & 90,5 & 90,5 & 100,0 \\
\hline & Total & 400 & 100,0 & 100,0 & \\
\hline \multicolumn{6}{|c|}{ Did you buy home sports equipment during the pandemic process? } \\
\hline \multirow[t]{4}{*}{ Valid } & & Frequency & Percent & $\begin{array}{c}\text { Valid } \\
\text { Percent }\end{array}$ & $\begin{array}{c}\text { Cumulative } \\
\text { Percent }\end{array}$ \\
\hline & Yes & 37 & 9,2 & 9,2 & 9,2 \\
\hline & No & 363 & 90,8 & 90,8 & 100,0 \\
\hline & Total & 400 & 100,0 & 100,0 & \\
\hline \multicolumn{6}{|c|}{ Have you had a pet in the pandemic process? } \\
\hline & & Frequency & Percent & $\begin{array}{c}\text { Valid } \\
\text { Percent }\end{array}$ & $\begin{array}{l}\text { Cumulative } \\
\text { Percent }\end{array}$ \\
\hline \multirow[t]{3}{*}{ Valid } & Yes & 58 & 14,5 & 14,5 & 14,5 \\
\hline & No & 342 & 85,5 & 85,5 & 100,0 \\
\hline & Total & 400 & 100,0 & 100,0 & \\
\hline
\end{tabular}

Table 4. Responses to the questions of whether there has been a change in the daily activities of residential users during the pandemic process

\begin{tabular}{|c|c|c|c|c|c|}
\hline \multicolumn{6}{|c|}{ If there is an elevator, do you use the common elevator in the pandemic process? } \\
\hline & & Frequency & Percent & $\begin{array}{c}\text { Valid } \\
\text { Percent }\end{array}$ & $\begin{array}{l}\text { Cumulative } \\
\text { Percent }\end{array}$ \\
\hline \multirow[t]{4}{*}{ Valid } & Yes & 185 & 46,3 & 46,3 & 46,3 \\
\hline & No & 105 & 26,2 & 26,2 & 72,5 \\
\hline & No elevator & 110 & 27,5 & 27,5 & 100,0 \\
\hline & Total & 400 & 100,0 & 100,0 & \\
\hline \multicolumn{6}{|c|}{$\begin{array}{l}\text { If you live in a residential sites are using the common use in the process of a } \\
\text { pandemic? }\end{array}$} \\
\hline \multirow[t]{5}{*}{ Valid } & & Frequency & Percent & $\begin{array}{c}\text { Valid } \\
\text { Percent }\end{array}$ & $\begin{array}{l}\text { Cumulative } \\
\text { Percent }\end{array}$ \\
\hline & Yes & 30 & 17,5 & 17,5 & 17,5 \\
\hline & No & 138 & 46,5 & 46,5 & 64,0 \\
\hline & $\begin{array}{l}\text { I don't live on the } \\
\text { site }\end{array}$ & 262 & 36,0 & 36,0 & 100,0 \\
\hline & Total & 400 & 100,0 & 100,0 & \\
\hline \multicolumn{6}{|c|}{ Do you do sports at home during the pandemic process? } \\
\hline \multirow[t]{4}{*}{ Valid } & & Frequency & Percent & $\begin{array}{l}\text { Valid } \\
\text { Percent }\end{array}$ & $\begin{array}{l}\text { Cumulative } \\
\text { Percent }\end{array}$ \\
\hline & Yes & 185 & 46,2 & 46,2 & 45,0 \\
\hline & No & 215 & 53,8 & 53,8 & 100,0 \\
\hline & Total & 400 & 100,0 & 100,0 & \\
\hline
\end{tabular}


Changes in Apartment and Site Type Houses During Covid-19 Pandemic

\begin{tabular}{|l|l|r|r|r|r|}
\hline If you are doing sports at home during the pandemic, in which unit of the house do \\
you do your sports?
\end{tabular}

If you have a pet, have you created a space (cage, cat house, dog house, aquarium, etc.) for it?

\begin{tabular}{|l|l|r|r|r|r|}
\hline Valid & Frequency & Percent & $\begin{array}{c}\text { Valid } \\
\text { Percent }\end{array}$ & $\begin{array}{c}\text { Cumulative } \\
\text { Percent }\end{array}$ \\
\cline { 2 - 6 } & Yes & 36 & 9,0 & 9,0 & 9,0 \\
\cline { 2 - 6 } & No & 22 & 5,5 & 5,5 & 14,5 \\
\cline { 2 - 6 } & I did not have & 342 & 85,5 & 85,5 & 100,0 \\
\cline { 2 - 6 } & Total & 400 & 100,0 & 100,0 & \\
\hline
\end{tabular}

\begin{tabular}{|c|c|c|c|c|c|}
\hline \multicolumn{6}{|c|}{ If you owned a pet, which unit of the dwelling did you put his place in? } \\
\hline \multirow[t]{8}{*}{ Valid } & & Frequency & Percent & $\begin{array}{c}\text { Valid } \\
\text { Percent }\end{array}$ & $\begin{array}{c}\text { Cumulative } \\
\text { Percent }\end{array}$ \\
\hline & $\begin{array}{l}\text { Living Areas } \\
\text { (Living Room etc.) }\end{array}$ & 32 & 8 & 8 & 8 \\
\hline & Kitchen & 4 & 1 & 1 & 9 \\
\hline & $\begin{array}{l}\text { Night Units } \\
\text { (Bedrooms, Kids } \\
\text { Rooms) }\end{array}$ & 2 & ,5 & ,5 & 9,5 \\
\hline & Entrance Hall & 4 & 1 & 1 & 10,5 \\
\hline & $\begin{array}{l}\text { Half Open and / or } \\
\text { Open Spaces } \\
\text { (balcony, terrace, } \\
\text { patio etc.) }\end{array}$ & 16 & 4 & 4 & 14,5 \\
\hline & I don't own pets & 342 & 85,5 & 85,5 & 100,0 \\
\hline & Total & 400 & 100,0 & 100,0 & \\
\hline
\end{tabular}

$64 \%$ of 290 participants who have elevators stated that they did not use elevators during the pandemic process, and $36 \%$ stated that they used elevators during this period. $17 \%$ of 168 people living on the site used 
common areas during the pandemic process, $83 \%$ did not use common areas within the site during this process. $46.2 \%$ of the respondents stated that they do sports during the pandemic process, while $53.8 \%$ do not do sports. Of the participants, $57.8 \%$ of the participants who do sports are living areas, $1.8 \%$ in the kitchen, $23.2 \%$ in the sleeping areas, $5.4 \%$ in the entrance of the house, $11.8 \%$ in the balcony and terrace does sports in places. During the pandemic period, $40.5 \%$ of those who bought sports equipment at home put their sports equipment in their living space, 35\% in night units, $8.3 \%$ in the entrance area, and $16.2 \%$ in the semi-open space. In this process, $62 \%$ of the 58 people who adopted pets created a special area for their pets in their residences. $38 \%$ did not create an area. $55 \%$ of those who adopt pets have created living spaces for their animals in living spaces, $7 \%$ in kitchen, $3 \%$ in night units, $7 \%$ in entrance areas and $28 \%$ in semi-open spaces.

Table 5. Answers to questions about cleaning spaces during the pandemic process

\begin{tabular}{|l|l|r|r|r|}
\hline \multicolumn{6}{|c|}{ I think that a clean and dirty area should be created for the entrance hall of } \\
the house.
\end{tabular}

I think that there should be a sterilization area in the entrance and elevators of the apartments.

\begin{tabular}{|l|l|r|r|r|r|}
\hline \multirow{7}{*}{ Valid } & $\begin{array}{c}\text { Frequen } \\
\text { cy }\end{array}$ & Percent & \multicolumn{1}{|c|}{$\begin{array}{c}\text { Valid } \\
\text { Percent }\end{array}$} & \multicolumn{2}{c|}{$\begin{array}{c}\text { Cumulative } \\
\text { Percent }\end{array}$} \\
\cline { 2 - 7 } & I agree & 338 & 84,5 & 84,5 & 84,5 \\
\cline { 2 - 6 } & $\begin{array}{l}\text { I } \\
\text { partiall } \\
\text { y agree }\end{array}$ & 48 & 12,0 & 12,0 & 96,5 \\
\cline { 2 - 6 } & $\begin{array}{l}\text { Disagre } \\
\text { e }\end{array}$ & 14 & 3,5 & 3,5 & 100,0 \\
\cline { 2 - 7 } & Total & 400 & 100,0 & 100,0 & \\
\hline
\end{tabular}

I think that the common areas should be sterilized continuously after the pandemic process.

\begin{tabular}{|c|c|c|c|c|c|}
\hline \multirow[t]{5}{*}{ Valid } & & $\begin{array}{l}\text { Frequen } \\
\text { cy }\end{array}$ & Percent & $\begin{array}{c}\text { Valid } \\
\text { Percent }\end{array}$ & $\begin{array}{l}\text { Cumulative } \\
\text { Percent }\end{array}$ \\
\hline & I agree & 349 & 87,3 & 87,3 & 87,3 \\
\hline & $\begin{array}{l}\text { I } \\
\text { partiall } \\
\text { y agree }\end{array}$ & 36 & 9,0 & 9,0 & 96,3 \\
\hline & $\begin{array}{l}\text { Disagre } \\
\text { e }\end{array}$ & 15 & 3,8 & 3,8 & 100,0 \\
\hline & Total & 400 & 100,0 & 100,0 & \\
\hline \multicolumn{6}{|c|}{$\begin{array}{l}\text { I think that frequent ventilation of the house will have a positive effect on the } \\
\text { places in the house. }\end{array}$} \\
\hline \multirow[t]{3}{*}{ Valid } & & $\begin{array}{l}\text { Frequen } \\
\text { cy }\end{array}$ & Percent & $\begin{array}{c}\text { Valid } \\
\text { Percent }\end{array}$ & $\begin{array}{l}\text { Cumulative } \\
\text { Percent }\end{array}$ \\
\hline & I agree & 367 & 91,8 & 91,8 & 91,8 \\
\hline & $\begin{array}{l}\text { I } \\
\text { partiall } \\
\text { y agree }\end{array}$ & 23 & 5,8 & 5,8 & 97,5 \\
\hline
\end{tabular}




\begin{tabular}{|l|l|r|r|r|r|}
\hline & $\begin{array}{l}\text { Disagre } \\
\mathrm{e}\end{array}$ & 10 & 2,5 & 2,5 & 100,0 \\
\cline { 2 - 5 } & Total & 400 & 100,0 & 100,0 & \\
\hline
\end{tabular}

$60.8 \%$ of those participating in the survey stated that they agreed that sterilization areas should be created in the entrance areas of the houses, $27 \%$ partially participated, and $12.3 \%$ stated that they did not. $84.5 \%$ of the respondents stated that they agreed that sterilization areas should be created in the entrance areas of the apartments and elevators, $12 \%$ partially participated, and $3.5 \%$ disagreed. $87.3 \%$ of those participating in the survey stated that they agree that common areas should be sterilized after the pandemic, 9\% partially agree and 3.8\% do not. 91.8\% of the respondents said I agree, 5.8\% partially agree, and $2.5 \%$ do not agree to the question that I think that frequent ventilation of the house will have a positive effect on the spaces in the residence.

Table 6. Answers to questions about the number of people living together and the type of house you live in

\begin{tabular}{|c|c|c|c|c|}
\hline \multicolumn{5}{|c|}{$\begin{array}{l}\text { What is the number of people you live together? }{ }^{*} \text { What is the type of the house you } \\
\text { live in? Crosstabulation }\end{array}$} \\
\hline & & \multicolumn{2}{|c|}{$\begin{array}{l}\text { What is the type of the house you } \\
\text { live in? }\end{array}$} & \multirow[t]{2}{*}{ Total } \\
\hline & & Apartment & $\begin{array}{l}\text { Site (multi-block } \\
\text { apartment) or } \\
\text { Gated communities }\end{array}$ & \\
\hline \multirow{5}{*}{$\begin{array}{l}\text { What is the } \\
\text { number of people } \\
\text { you live together? }\end{array}$} & Single & 20 & 7 & 27 \\
\hline & 2 & 48 & 30 & 78 \\
\hline & 3 & 56 & 28 & 84 \\
\hline & 4 & 73 & 39 & 112 \\
\hline & 5 and over & 65 & 34 & 99 \\
\hline \multicolumn{2}{|l|}{ Total } & 262 & 138 & 400 \\
\hline
\end{tabular}

Comparing the number of people living together with the type of house, $74 \%$ of the people living alone live in apartment-type house, while $26 \%$ live on the site. While $62 \%$ of the families with 2 people live in apartmenttype house, $38 \%$ of them live on the site. While $67 \%$ of the families with 3 people live in apartment-type house, 33\% of them live on the site. $65 \%$ of the families with 4 people live in apartment-type house although $35 \%$ of them live on the site. Also $65 \%$ of the families with 5 people live in apartment-type house although $35 \%$ of them live on the site.

Table 7. Answers to the questions on the number of people living together and the number of rooms

\begin{tabular}{|c|c|c|c|c|c|c|c|}
\hline \multicolumn{8}{|c|}{$\begin{array}{l}\text { How many rooms do you live in? } * \text { What is the number of people you live } \\
\text { together? Crosstabulation }\end{array}$} \\
\hline & & \multicolumn{5}{|c|}{ What is the number of people you live together? } & \multirow[t]{2}{*}{ Total } \\
\hline & & Single & 2 & 3 & 4 & 5 and over & \\
\hline \multirow{4}{*}{$\begin{array}{l}\text { How } \\
\text { many } \\
\text { rooms do }\end{array}$} & $1+1$ & 6 & 1 & 0 & 0 & 0 & 7 \\
\hline & $2+1$ & 12 & 18 & 13 & 11 & 6 & 60 \\
\hline & $3+1$ & 8 & 53 & 56 & 77 & 69 & 263 \\
\hline & $4+1$ & 1 & 6 & 15 & 21 & 17 & 60 \\
\hline
\end{tabular}




\begin{tabular}{|l|l|l|l|l|l|l|l|}
\hline $\begin{array}{l}\text { you live } \\
\text { in? }\end{array}$ & $5+1$ & 0 & 0 & 0 & 3 & 7 & 10 \\
\hline Total & & 27 & 78 & 84 & 112 & 99 & 400 \\
\hline
\end{tabular}

When comparing the number of rooms and the number of people living in the housing inhabited, it is seen that $86 \%$ of the people living in $1+1$ housing type live alone and $14 \%$ of them have 2 people. While $20 \%$ of those living in $2+1$ housing type live alone, 30\% live with two people, $22 \%$ with three people, $18 \%$ with four people, and $10 \%$ with 5 people or more. Of those living in $3+1$ type of house, $2 \%$ live alone, $20 \%$ with two people, $22 \%$ with three people, $30 \%$ with three people, $26 \%$ with five people or more. Of those living in $4+1$ housing type, $1 \%$ live alone, $10 \%$ live with two people, $25 \%$ with three people, $35 \%$ with four people, $39 \%$ with 5 or more people. For those living in $5+1$ housing type; $30 \%$ are families with 4 people and $70 \%$ are families with 5 or more people.

Table 8. Comparison of the number of rooms in the house and house preferences during the pandemic process

\begin{tabular}{|c|c|c|c|c|c|c|c|}
\hline \multicolumn{8}{|c|}{$\begin{array}{l}\text { Have your housing preferences changed during the pandemic process? }{ }^{*} \text { How many } \\
\text { rooms do you live in? Crosstabulation }\end{array}$} \\
\hline & & \multicolumn{5}{|c|}{ How many rooms do you live in? } & \multirow[t]{2}{*}{ Total } \\
\hline & & $1+1$ & $2+1$ & $3+1$ & $4+1$ & $5+1$ & \\
\hline \multirow{2}{*}{$\begin{array}{l}\text { Have your housing } \\
\text { preferences changed } \\
\text { during the pandemic } \\
\text { process? }\end{array}$} & Yes & 3 & 15 & 101 & 23 & 4 & 146 \\
\hline & No & 4 & 45 & 162 & 37 & 6 & 254 \\
\hline \multicolumn{2}{|l|}{ Total } & 7 & 60 & 263 & 60 & 10 & 400 \\
\hline
\end{tabular}

When comparing the number of rooms in the houses of the participants and the change in their housing preferences during the pandemic process, $3 \%$ of those whose housing preferences changed are in $1+1$ housing type, $10 \%$ in $2+1$ housing type, $69 \%$ in $3+1$ housing type, $15 \%$ in $4+1$ housing type and $3 \%$ of them live in $5+1$ housing type.

Table 9. Answers to questions about the space features needed during the pandemic process

\begin{tabular}{|l|l|l|l|}
\hline \multicolumn{2}{|l|}{} & Count & Column Responses \% \\
\hline Please mark the & Garden & 285 & $33,1 \%$ \\
\cline { 2 - 4 } space features you \\
$\begin{array}{l}\text { need during the } \\
\text { pandemic process. }\end{array}$ & Larger balcony & 180 & $20,9 \%$ \\
\cline { 2 - 4 } & Larger house & 88 & $10,2 \%$ \\
\cline { 2 - 4 } & More rooms & 71 & $8,2 \%$ \\
\cline { 2 - 4 } & Social areas & 179 & $20,8 \%$ \\
\cline { 2 - 4 } & I don't need & 50 & $5,8 \%$ \\
\cline { 2 - 4 } & Others & 8 & $0,9 \%$ \\
\cline { 2 - 3 } & Total & 400 & $100,0 \%$ \\
\hline
\end{tabular}

When asked about the places needed during the pandemic process, $33.1 \%$ of the respondents need a garden, $20.9 \%$ a larger balcony, $10.2 \%$ a wider house, $8.2 \%$ more rooms, $20.8 \%$ stated social areas and $5.8 \%$ stated that they do not need anything. 
Table 10. Answers to questions about changes in living room

\begin{tabular}{|l|l|l|l|}
\hline \multicolumn{2}{|l|}{} & Count & $\begin{array}{l}\text { Column } \\
\text { Responses \% }\end{array}$ \\
\hline $\begin{array}{l}\text { What changes have } \\
\text { you made in Living }\end{array}$ & $\begin{array}{l}\text { I changed the seating } \\
\text { arrangement }\end{array}$ & 98 & $19,2 \%$ \\
\cline { 2 - 4 } $\begin{array}{l}\text { Areas (Living Room } \\
\text { etc.)? }\end{array}$ & I bought furniture & 23 & $4,5 \%$ \\
\cline { 2 - 4 } & I had to replace the TV & 22 & $4,3 \%$ \\
\cline { 2 - 4 } & I bought flowers & 82 & $16,1 \%$ \\
\cline { 2 - 4 } & $\begin{array}{l}\text { I bought / replaced } \\
\text { the lighting furniture }\end{array}$ & 18 & $3,5 \%$ \\
\cline { 2 - 4 } & I bought decoration \\
\cline { 2 - 4 } & $\begin{array}{l}\text { I did not make } \\
\text { changes }\end{array}$ & 215 & $7,5 \%$ \\
\hline & Others & 14 & $2,7 \%$ \\
\cline { 2 - 4 } & Total & 400 & $100,0 \%$ \\
\hline
\end{tabular}

When asked what kind of changes you have made in your living spaces; $19.2 \%$ changed the seating arrangement, $4.5 \%$ bought furniture, $4.3 \%$ changed the location of the television, $16.1 \%$ bought flowers, 3.5\% bought lighting elements or changed their location, $7.5 \%$ stated that they bought decoration elements, $42.2 \%$ stated that they did not make any changes.

Table 11. Answers to questions about changes in kitchen

\begin{tabular}{|c|c|c|c|}
\hline & & Count & $\begin{array}{l}\text { Column } \\
\text { Responses \% }\end{array}$ \\
\hline \multirow{11}{*}{$\begin{array}{l}\text { What } \\
\text { changes did } \\
\text { you make for } \\
\text { the kitchen? }\end{array}$} & $\begin{array}{lr}\text { I changed the seating } \\
\text { arrangement }\end{array}$ & 16 & $3,3 \%$ \\
\hline & I bought furniture & 4 & $0,8 \%$ \\
\hline & $\begin{array}{l}\text { I bought / replaced the lighting } \\
\text { element }\end{array}$ & 4 & $0,8 \%$ \\
\hline & $\begin{array}{l}\text { I created a cleaning area for food } \\
\text { from outside }\end{array}$ & 68 & $14,0 \%$ \\
\hline & $\begin{array}{l}\text { I created a storage area for food } \\
\text { from outside }\end{array}$ & 61 & $12,6 \%$ \\
\hline & I bought a TV & 5 & $1,0 \%$ \\
\hline & $\begin{array}{l}\text { I bought or arranged storage } \\
\text { furniture (closet, etc.) }\end{array}$ & 25 & $5,1 \%$ \\
\hline & I bought flowers & 43 & $8,8 \%$ \\
\hline & I did not make changes & 254 & $52,3 \%$ \\
\hline & Other & 6 & $1,2 \%$ \\
\hline & Total & 400 & $100,0 \%$ \\
\hline
\end{tabular}

When asked what kind of changes have you made in your kitchen, the respondents; $52.3 \%$ did not make changes, $3.3 \%$ changed the seating arrangement, $0.8 \%$ bought furniture, $0.8 \%$ bought lighting elements, $14 \%$ created a clean area for items coming from outside, $\% 12.6 \%$ of them stated that they created a storage area for food coming from outside, $1 \%$ bought a television, 5.1\% bought or arranged storage furniture, and 8.8\% stated that they bought flowers. 
Table 12. Answers to questions about changes in wet areas (bathroom and / or toilet)

\begin{tabular}{|c|c|c|c|}
\hline & & Count & $\begin{array}{l}\text { Column } \\
\text { Responses \% }\end{array}$ \\
\hline \multirow{7}{*}{$\begin{array}{l}\text { What changes } \\
\text { have you made to } \\
\text { Wet Areas } \\
\text { (Bathroom and / } \\
\text { or Toilet)? }\end{array}$} & $\begin{array}{l}\text { I bought / replaced the lighting } \\
\text { furniture }\end{array}$ & 8 & $1,8 \%$ \\
\hline & $\begin{array}{l}\text { I bought or arranged storage } \\
\text { furniture (closet, etc.) for cleaning } \\
\text { products }\end{array}$ & 52 & $11,7 \%$ \\
\hline & $\begin{array}{l}\text { I bought or arranged storage } \\
\text { furniture (closet, etc.) for dirty } \\
\text { clothes }\end{array}$ & 32 & $7,2 \%$ \\
\hline & I created a space for outside items. & 51 & $11,4 \%$ \\
\hline & I did not make changes & 301 & $67,5 \%$ \\
\hline & Other & 2 & $0,4 \%$ \\
\hline & Total & 400 & $100,0 \%$ \\
\hline
\end{tabular}

When asked what kind of changes have you made in wet areas (toilet, bathroom), the respondents; $67.5 \%$ did not make changes, $1.8 \%$ bought or replaced lighting elements, $11.7 \%$ bought or arranged storage furniture for cleaning materials, $7.2 \%$ bought or arranged storage furniture for dirty laundry and $11.4 \%$ stated that it created an area for items coming from outside.

Table 13. Answers to questions about changes in bedroom

\begin{tabular}{|l|l|l|l|}
\hline \multicolumn{2}{|c|}{} & $\begin{array}{l}\text { Cou } \\
\text { nt }\end{array}$ & $\begin{array}{l}\text { Column } \\
\text { Responses \% }\end{array}$ \\
\hline \multirow{2}{*}{$\begin{array}{l}\text { What } \\
\text { changes } \\
\text { have you } \\
\text { made for } \\
\text { the }\end{array}$} & I changed the furniture. & 36 & $9,0 \%$ \\
\cline { 2 - 4 } Bedroom & I created a space for outside items. & 9 & $2,3 \%$ \\
\cline { 2 - 4 } & I bought / replaced the lighting furniture & 9 & $2,3 \%$ \\
\cline { 2 - 4 }$?$ & I bought furniture & 23 & $5,8 \%$ \\
\cline { 2 - 4 } & I did not make changes & 312 & $78,0 \%$ \\
\cline { 2 - 4 } & Others & 11 & $2,8 \%$ \\
\cline { 2 - 4 } & Total & 400 & $100,0 \%$ \\
\hline
\end{tabular}

When asked about what kind of changes you have made in your bedroom, the respondents; $78 \%$ of them stated that they did not make changes, $9 \%$ of them changed the location of the furniture, $2.3 \%$ stated that they created an area for the items coming from outside, 5.8\% stated that they bought furniture.

Table 14. Answers to questions about changes in entrance hall

\begin{tabular}{|l|l|l|l|}
\hline \multicolumn{2}{|l|}{} & Count & $\begin{array}{l}\text { Column } \\
\text { Responses \% }\end{array}$ \\
\hline $\begin{array}{l}\text { What changes } \\
\text { did you make } \\
\text { for } \begin{array}{l}\text { Entrance } \\
\text { Hall? }\end{array}\end{array}$ & $\begin{array}{l}\text { I created a space for outside items } \\
\text { furniture }\end{array}$ & 30 & $7,5 \%$ \\
\cline { 2 - 4 } & I bought shoe cabinet & 1 & $0,3 \%$ \\
\cline { 2 - 4 } & I bought a cloakroom & 5 & $1,3 \%$ \\
\cline { 2 - 4 } & I bought flowers & 38 & $9,5 \%$ \\
\cline { 2 - 4 } & I did not make changes & 3 & $0,8 \%$ \\
\cline { 2 - 4 } & Others & 313 & $78,3 \%$ \\
\cline { 2 - 4 } & Total & 400 & $10,5 \%$ \\
\hline
\end{tabular}


When asked what kind of changes you made in the entrance hall during the pandemic process, the respondents; $78.3 \%$ of them answered that they did not make any changes. Of the survey respondents, $7.5 \%$ created a space for items coming from outside, $0.3 \%$ bought or replaced lighting elements, $1.3 \%$ bought shoe racks, $9.5 \%$ bought a cloakroom, $0,8 \%$ bought flowers, marked those options.

Table 15. Answers to questions about changes in children's room

\begin{tabular}{|l|l|l|l|}
\hline \multicolumn{2}{|c|}{} & Count & $\begin{array}{l}\text { Column } \\
\text { Responses \% }\end{array}$ \\
\hline \multirow{2}{*}{$\begin{array}{l}\text { What } \\
\text { changes } \\
\text { have you } \\
\text { made for } \\
\text { the } \\
\text { Children's } \\
\text { Room? }\end{array}$} & There is no children's room. & 57 & $13,0 \%$ \\
\cline { 2 - 4 } & I created a distance learning venue. & 59 & $13,5 \%$ \\
\cline { 2 - 4 } & I created a playground. & 34 & $7,8 \%$ \\
\cline { 2 - 4 } & I created a space for outside items. & 19 & $4,3 \%$ \\
\cline { 2 - 4 } & furniture & 8 & $1,8 \%$ \\
\cline { 2 - 4 } & I bought furniture & 2 & $0,5 \%$ \\
\cline { 2 - 4 } & I did not make changes & 257 & $58,7 \%$ \\
\cline { 2 - 4 } & Other & 2 & $0,5 \%$ \\
\cline { 2 - 4 } & Total & 400 & $100,0 \%$ \\
\hline
\end{tabular}

When asked what kind of changes have you made for the children's room, $13 \%$ of the respondents stated that they do not have a children's room and $58.7 \%$ did not make any changes. Of the respondents, $13.5 \%$ created a distance education space, $7.8 \%$ created a playground, $4.3 \%$ created a space for items coming from outside, $1.8 \%$ bought or replaced lighting elements, $0.5 \%$ bought furniture of them stated that.

Table 16. Answers to questions about changes in to half-Open and / or Open Spaces (Balcony, Terrace, Patio, etc.)

\begin{tabular}{|c|c|c|c|}
\hline & & Count & $\begin{array}{l}\text { Column } \\
\text { Responses \% }\end{array}$ \\
\hline \multirow{10}{*}{$\begin{array}{l}\text { What changes } \\
\text { have you made } \\
\text { to half-Open } \\
\text { and / or Open } \\
\text { Spaces } \\
\text { (Balcony, } \\
\text { Terrace, Patio, } \\
\text { etc.)? }\end{array}$} & $\begin{array}{l}\text { No Half-Open and / or Open } \\
\text { Space. }\end{array}$ & 12 & $2,2 \%$ \\
\hline & I bought / planted flowers & 105 & $19,5 \%$ \\
\hline & $\begin{array}{l}\text { I created a space for outside } \\
\text { items. }\end{array}$ & 0 & $0,0 \%$ \\
\hline & $\begin{array}{l}\text { I bought / replaced the lighting } \\
\text { furniture }\end{array}$ & 82 & $15,2 \%$ \\
\hline & I bought decoration elements & 35 & $6,5 \%$ \\
\hline & I bought a sitting furniture & 34 & $6,3 \%$ \\
\hline & $\begin{array}{l}\text { I bought / planted Field Crops } \\
\text { (Tomato, Pepper, Basil etc.) }\end{array}$ & 59 & $10,9 \%$ \\
\hline & I did not make changes & 209 & $38,8 \%$ \\
\hline & Other & 3 & $0,6 \%$ \\
\hline & Total & 400 & $100,0 \%$ \\
\hline
\end{tabular}

When asked what kind of changes you have made in semi-open and / or open spaces (balcony, terrace, veranda etc.) 38.8\% stated that they did not make any changes and $2.2 \%$ stated that they did not have a semi-open or open space. Of the respondents, $19.5 \%$ bought or planted flowers, $15.5 \%$ bought or replaced lighting elements, 6.5\% bought decoration 
elements, $6.3 \%$ bought seating elements, $10.9 \%$ bought or planted field crops (tomato, pepper, basil, etc.) of them stated that.

Table 17. Comparison of the space features needed in the pandemic process and the features of the house where you live

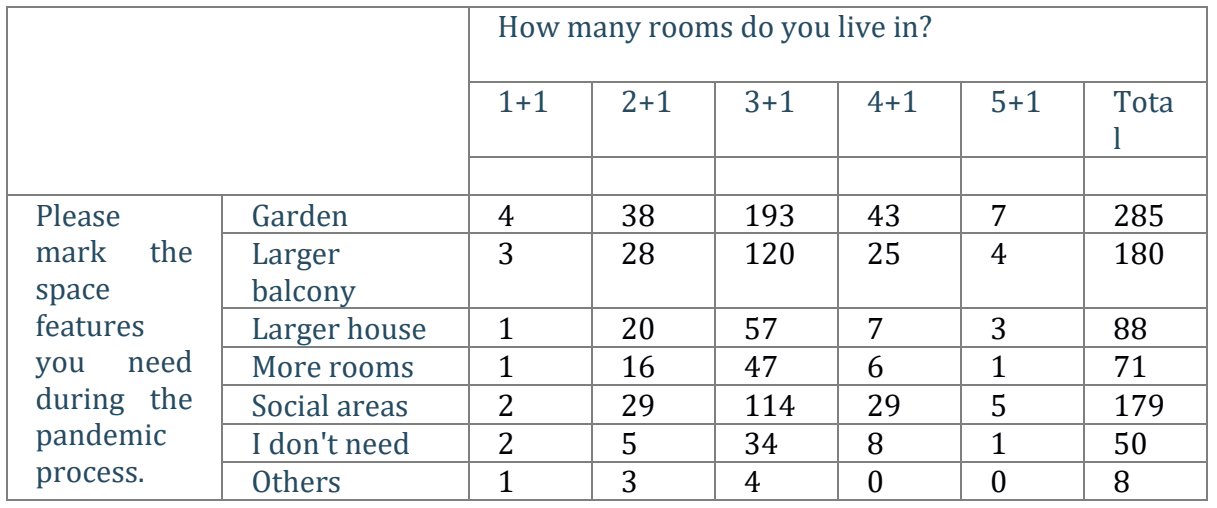

When comparing the number of rooms of the houses with live and the spaces they need during the pandemic process in which the respondents, those who need a garden; $1.5 \%$ of them live in $1+1$ housing type, $13 \%$ of them live in $2+1$ housing type, $68 \%$ of them live in $3+1$ housing type, $15 \%$ of them live in $4+1$ housing type, $2.5 \%$ of them live in $5+1$ housing type. Those who need a larger balcony; $2 \%$ of them live in $1+1$ housing type, $16 \%$ of them live in $2+1$ housing type, $66 \%$ of them live in $3+1$ housing type, $14 \%$ of them live in $4+1$ housing type and $2 \%$ of them live in $5+1$ housing type. Those who need a larger house; $2 \%$ of them live in $1+1$ housing type, $\% 23$ of them live in $2+1$ housing type, $65 \%$ of them live in $3+1$ housing type, $9 \%$ of them live in $4+1$ housing type and $1 \%$ of them live in $5+1$ housing type. Also, those who need more room; $1 \%$ of them live in $1+1$ housing type, $23 \%$ of them live in $2+1$ housing type, $66 \%$ of them live in $3+1$ housing type, $8 \%$ of them live in $4+1$ housing type, $1 \%$ of them live in $5+1$ housing type. Moreover, those who need social space; $2 \%$ of them live in $1+1$ housing type, $16 \%$ of them live in $2+1$ housing type, $63 \%$ of them live in $3+1$ housing type, $16 \%$ of them live in $4+1$ housing type, $3 \%$ of them live in $5+1$ housing type.

Table 18. Comparison of the space features needed in the pandemic process and the number of people living together

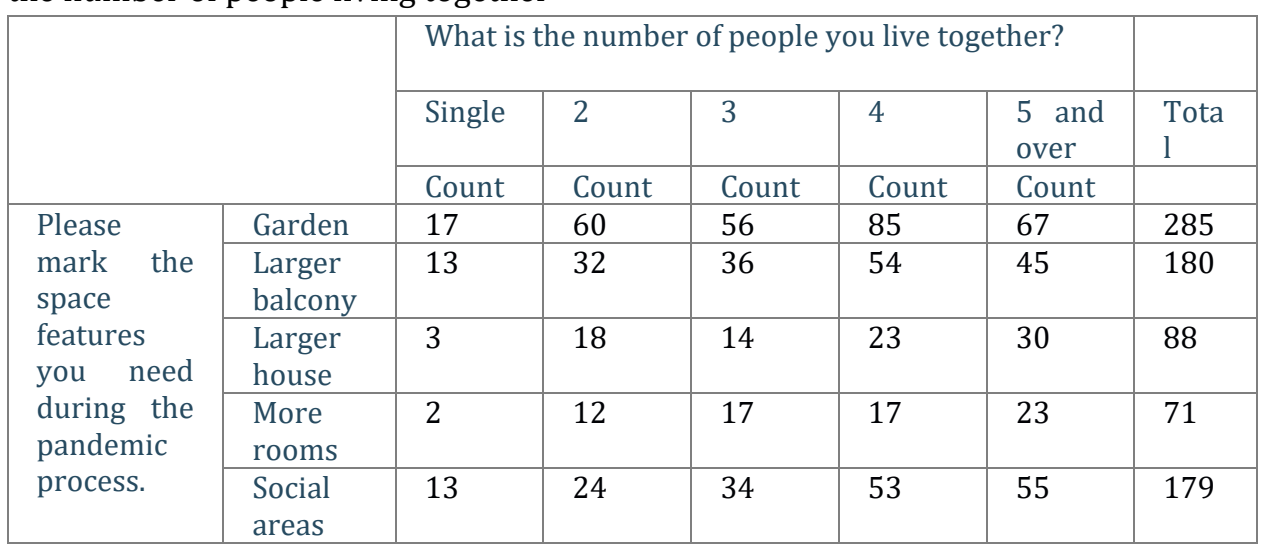




\begin{tabular}{|l|l|l|l|l|l|l|c|}
\hline & $\begin{array}{l}\text { I don't } \\
\text { need }\end{array}$ & 5 & 11 & 12 & 9 & 13 & 50 \\
\cline { 2 - 8 } & Others & 2 & 1 & 0 & 3 & 2 & 8 \\
\hline
\end{tabular}

When comparing the number of people living together with the space features needed during the pandemic process; 50 people $(12.5 \%)$ stated that they do not need any space. Those who need a garden; $6 \%$ live with one person, $21 \%$ live with two people, $19 \%$ live with three people, $30 \%$ live with four people, $25 \%$ live with five or more people. Those who need a larger balcony; $7 \%$ live alone, $18 \%$ live with two people, $20 \%$ live with three people, $30 \%$ with live four people, and $25 \%$ live with five or more people. Those who need a larger house; $4 \%$ live alone, $20 \%$ live with two people, $16 \%$ live with three people, $26 \%$ live with four people, and $34 \%$ live with five or more people. Those who need more room; $3 \%$ live alone, $17 \%$ live with two people, $24 \%$ live with three people, $24 \%$ live with four people, and $32 \%$ live with five or more people. Also those who need social areas; $7 \%$ live alone, $13 \%$ live with two people, $19 \%$ live with three people, $30 \%$ live with four people, $31 \%$ live with five or more people.

\section{RESULTS}

Houses are the most common type of building in cities, which are the most needed and produced compared to other buildings, and also houses supply the basic living needs of people such as; resting, security, nutrition and establishing a family. In the Covid-19 pandemic, people must spend more time at their houses. Personal precautions are of great importance in preventing transmission of the disease. In addition, the situation of

Figure 12. The graphic of the space features needed during the pandemic process. preventing the epidemic and not getting sick has emerged thanks to the careful behaviour of the people and by staying in the house. During this period, it was understood that the house was the safest place. According to the results of the research, during the pandemic process, the spaces needed by houses users, garden, larger balcony, larger house, more rooms, and social spaces (Figure 12).

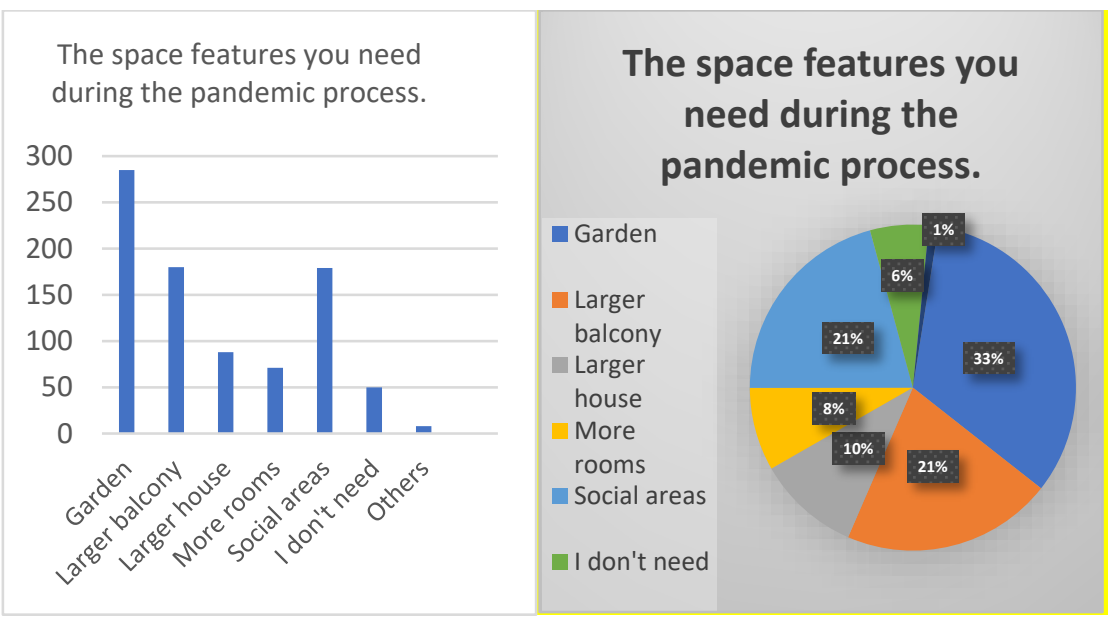

In this process, it is seen that most research participants need open and/or semi-open spaces such as balconies, gardens, and social areas. It 
turns out that designers should also give importance to semi-open and open space designs while designing apartment houses. Compared to the number of people living together and the space characteristics needed in the pandemic process; 3 and more people who living with families need spatial features such as a larger balcony, larger house, garden, social area. As the number of family members increases, their needs for house's space features also increase. It has been determined that most of the apartment house users living in type of $3+1$ apartment housing change in their choice of housing. They stated that the residents living in $3+1$ apartment housing type will prefer the houses with gardens, larger balconies and houses with larger square meters, houses with more rooms and social areas. $3+1$ type of housing usually has built for family housing in Turkey. However, during the pandemic process, it has been determined that $3+1$ house types do not supply the needs of the users and the users are not satisfied with this type of house (Figure 13).

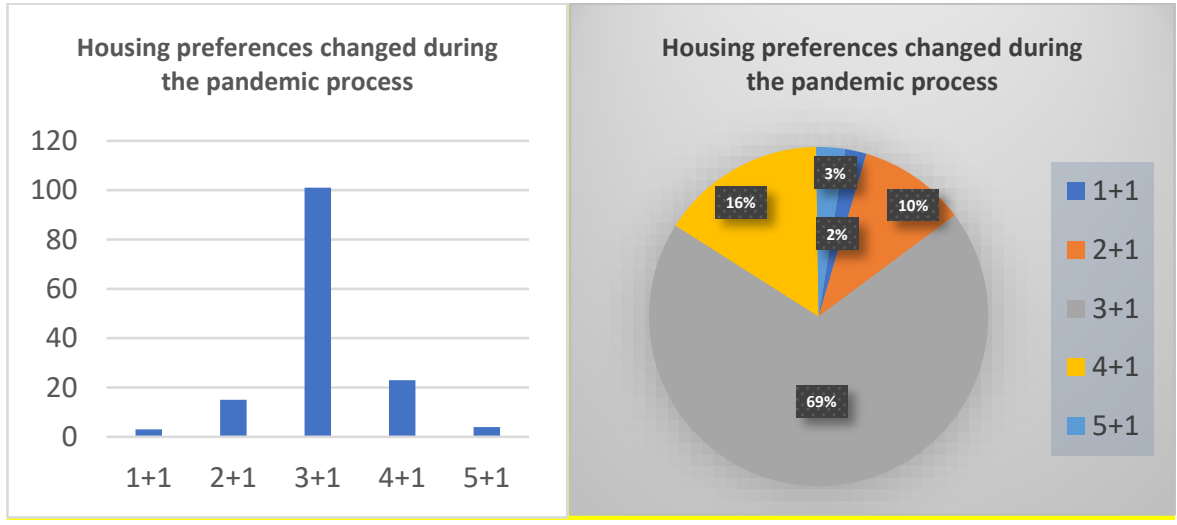

During the pandemic process, they stated that most of the apartment house users do not use common areas such as elevators and social areas, and that the technical equipment of the sterilization areas in these areas should be designed. It is concluded that people will continue to need sterile spaces after the pandemic. This result emerges as a problem to be solved in terms of architectural discipline. During this period, apartment residents who had to spend most of their daily lives in their residences stated that they adopted pets, did their jobs from home, started growing ornamental and field plants, bought sports equipment for their residences and started doing sports. In addition, as a result of continuing education-training remotely during the pandemic process, the need for education areas for children in residences has emerged. Thus, the lifestyles of users in their homes have changed or new lifestyles have been added. In addition, they stated that apartment residents created storage and sterilization areas for their belongings coming from outside in the entrance, kitchen and wet areas of their residences and that such areas should be available for the residences. As a result of the research, the apartment house users stated that they longed for nature as a result of their isolation in their houses. As a result, they stated that they mostly
Figure 13. The graphic of housing preferences changed during the pandemic process. 
made changes in their open / semi-open spaces and started to use these areas more. They stated that they made decoration in their open and / or semi-open spaces, bought sitting and lighting elements, and bought / planted flowers and / or field plants. An unexpected or unprepared situation has been encountered in the world, as a result, it is necessary to design flexible houses that will appeal to changing, added or different life styles.

\section{CONFLICT OF INTEREST}

The authors declared that this study has not conflict of interest.

\section{FINANCIAL DISCLOSURE}

The authors declared that this study has received no financial support.

\section{ETHICS COMMITTEE APPROVAL}

Ethics committee approval was not required for this article.

\section{LEGAL PUBLIC/PRIVATE PERMISSIONS}

In this research, the necessary permissions were obtained from the relevant participants (individuals, institutions, and organizations) during the survey and in-depth interviews.

\section{REFERENCES}

Ak, M. (2011). 19. Yüzyılda Antalya'da kolera salgını. Uluslararası Sosyal Araştırmalar Dergisi, 17, 254-268.

Alga, R. (2005). Yaşam döngüsüne bağlı olarak konut tasarımını etkileyen faktörler İstanbul Teknik Üniversitesi].

Arcan, E. F., \& Evci, F. (1999). Mimari tasarıma yaklaşım. Tasarım Yayın Grubu.

Aslan, R. (2020). Tarihten günümüze epidemiler, pandemiler ve Covid19. Göller Bölgesi Aylık Ekonomi Ve Kültür Dergisi, 8(55), 36-41.

Balamir, M. (1994). "Kira Evi"nden "Kat Evleri”ne apartmanlaşma: bir zihniyet dönüşümü tarihçesinden kesitler. Mimarlık, 260, 29-32.

Barbarossa, L. (2020). The post pandemic city: challenges and opportunities for a non-motorized urban environment. An Overview of Italian Cases. https://doi.org/10.3390/su12177172.

Bayazıt, N., \& Yüksel, Y. D. (1996). Toplu konut projelerinde çocuklar için mekanlar, diğerlerinin konut sorunları. TBMMOB Mimarlar Odası Yayını, 432-445.

Bozboğan, S. (2015). Modernizm ve ulusun inşası: erken Cumhuriyet dönemi Türkiye'sinde Mimari Kültür. Metis Yayınları.

Chotiner, I. (2020). Pandemi tarihi nasıl değiștirir?

Courbusier, L. (2015). Bir mimarlığa doğru. Yapı Kredi Yayınları. 
Demirarslan, D. (2020). Tarihsel süreçte yatak odalarının gelişimi, . urnal of Social and Humanities Sciences Research, 7(52), 860-884.

Dinçer, Ö. (2005). Mimari Mekan Organizasyon Sürecinde Mekansal Hem yüzey Birleşim ve Entegrasyon Kavramlarının Analizi.

Ensarioğlu, S., \& Ensarioğlu, A. (2020). Pandemi sürecinin "Evrensel Tasarım" ilkelerine etkileri. International Journal of Social Humanities Sciences Research (JSHSR) 7(55), 1673-1680.

Erturan, E. M., Özer Yaman, G., \& Yıldırım Ateş, A. (2020). Koronavirüs pandemisi sonucu uzaktan eğitim uygulaması ile konutlarda oluşan eğitim mekânları. In Recent Advances in Social Science, Education and Humanities (pp. 135-155). Gece Publishing.

Esen, A. (2017). Sıhhî-İ İctimâî Coğrafya kitaplarına göre İç Anadolu'da görülen salgın hastalıklar (1922-1926). Ankara Üniversitesi Türk Inkılâp Tarihi Enstitüsü Atatürk Yolu Dergisi(60), 73-90.

Gönen, E. (1990). Mutfak çalıșma mer. optimum iş yük. ve antropometrik ölçüm ilişkisi üzerine ergonomik bir araştırma (Vol. 408). M.P.M.

Görgülü, T. (2016). Apartman tipolojisinde dünden bugüne; kira apartmanından "Rezidans'a” geçiş. TÜBA-KED, Türkiye Bilimler Akademisi Kültür Envanteri Dergisi, 14.

Gündoğdu, N. S. (2019). Nüfus artışına bağlı olarak yaşam alanı değişimi: dar alanlı konutlar T.C. Maltepe Üniversitesi Fen Bilimleri Enstitüsü].

Hacıbaloğlu, M. (1989). Geleneksel Türk Evi ve çağımıza ulaşamamasının nedenleri. G.Ü. Müh. Mim. Fak.

Hercules, W. J., Anderson, D. C., \& M., S. (2020). Architecture-a critical ingredient of pandemic medicine: an open letter to policy makers. HERD: Health Environments Research \& Design Journal, 13(3), 247-252.

Kırık, A. M., Var, S., Özkoçak, V., \& Darıcı, S. (2020). Pandemi dönemlerinde iletişim ve algı yönetimi, yeni koronavirüs hastalığı (Covid19) örneği. Akademik Sosyal Araştırmalar Dergisi,, 104(8), 36-57.

Kostof, S. (1995). History of Architecture. Oxford University Press.

Oruç, Ö. (2009). Islak mekân tasarımının ve bu tasarımda kullanılan donatı elamanlarının yaşam tarzı ve davranış biçimi bakımından incelenmesi, Adana Örneği Çukurova Üniversitesi].

Özkoçak, V., Koç, F., \& Gültekin, T. (2020). Pandemilere antropolojik bakış: koronavirüs (Covid-19) örneği. Turkish Studies, 15(2), 1183-1195.

Pakalın, M. Z. (1983). Osmanlı Tarih Deyimleri ve Terimleri Sözlüğü (Vol. I-III).

Parvaresh, H. (2013). Mekansal kurgu özellikleri açısından İran, YazdTürkiye, Şanlıurfa geleneksel konutları üzerine araştırma 
Reynolds D.L., Garay J.R., Deamond S.L., Moran M.K., W., G., \& R., S. (2008). Understanding, compliance and psychological impact of the SARS quarantine experience. Epidemiol Infect(136), 997-1007.

URL-1. https://tr.wikipedia.org/wiki/COVID-19_pandemisi.

URL-2. https://forumusa.com/amerika-usa-amerika-birlesik-devletleri/is panyol-gribi-zamaninda-hayat-unutulan-salgin-da-neler-yasanmisti/.

URL-3. URL-3:https://www.tr24.com/kara-olum-vebadan-koleraya-insan ligin-salgin-hastaliklarla-imtihani/amp/.

URL-4. https://medium.com/@kampusavrupa/veba-an\%C4\%B1t\%C4\% B1-f5b9ba648078.

URL-5. http://borceningezileri.blogspot.com/2018/01/bratislava-slovak ya-gezi-notlari.html.

URL-6. https://mapio.net/pic/p-6530345/.

URL-7. https://www.yenisafak.com/foto-galeri/hayat/hastaliklara-gecitvermeyen-karantina-adasi-tahaffuzhane-2014660?page=3.

URL-8. https://www.youtube.com/watch?v=yZ_qmThPOno\&t=6297s.

Yıldırım, K. (1999). Konut mutfaklarınin mekan ve donatı organizasyonunda ergonomik yaklaşım Gazi Üniversitesi]. Ankara.

Yıldırım, N. (2015). İstanbul'da sağlık hayatı, antik çağdan XXI. Yüzyıla büyük İstanbul Tarihi (Vol. 4). İBB Kültür AȘ.

Yıldız, O. (2017). Pandemik enfeksiyonlar ve seyahat. Türkiye Klinikleri Infectious Diseases-Special Topics, 10(3), 305-312.

\section{Resume}

Gonca Özer Yaman is currently works at Bingöl University Department of Architecture as a doctoral lecturer. His research focuses on sustainable architecture, ecological architecture, energy efficient building design.

Elif Merve Erturan currently works at Konya Technical University, Department of Architecture, as an research assistant She received his M.Arch in architecture from Selçuk University. She is countinuing her PhD in architectural design at Konya Technical University.

Ayşe Yıldırım Ates currently works as a research assistant at the Department of Architecture, Akdeniz University. She is continuing her PhD in Department of Architecture at Faculty of Architecture and Design, Konya Technical University. Her research focuses on housing design, gated communities, universal design and architectural accessibility. 